Article

\title{
Feminist Stereotypes and Women's Roles in Spanish Radio Ads
}

\author{
Anna Fajula *, Mariluz Barbeito, Estrella Barrio, Ana Maria Enrique and Juan José Perona \\ Department of Advertising, Public Relations and Audiovisual Communication, Autonomous University of Barcelona, \\ 08193 Bellaterra, Spain; E-Mails: anna.fajula@uab.cat (A.F.), mariluz.barbeito@uab.cat (M.B.), \\ estrella.barrio@uab.cat (E.B.), anamaria.enrique@uab.cat (A.M.E.), juanjose.perona@uab.cat (J.J.P.)
}

* Corresponding author

Submitted: 21 October 2020 | Accepted: 19 January 2021 | Published: 23 March 2021

\begin{abstract}
This article takes a quantitative approach to Spanish radio advertising and the stereotypes and female roles that it broadcasts in a medium that has traditionally had high female audience rates in our country. From content analysis of 679 radio ads extracted from the 3 main general Spanish radio stations and collected 10 years apart, the study attempts to show the evolution (or regression) of how radio advertising portrays women. The radio in Spain has always been a medium anchored in the real world that has also provided some degree of space to broadcast social movement. \#MeToo, as a phenomenon promoting female empowerment, was no exception. Therefore, this longitudinal study aims to demonstrate whether the social movements that led to increased female activism have been reflected in a change of roles and stereotypes projected by radio advertising messages. The work presented here looks at the concept of role from a dual perspective: firstly, it focuses on the role played by female voices in radio advertising items. Secondly, it works on the concept of role by assimilating it into the female image projected in radio advertising items. The results obtained between the two samples are remarkably similar, demonstrating a clear tendency to polarise the female image and confirming that women are still being portrayed in significantly traditional roles.
\end{abstract}

\section{Keywords}

\#MeToo movement; advertising; feminism; gender studies; radio; roles; Spain; stereotypes; women

\section{Issue}

This article is part of the issue "Gender and Media: Recent Trends in Theory, Methodology and Research Subjects" edited by Sofie Van Bauwel (Ghent University, Belgium) and Tonny Krijnen (Erasmus University Rotterdam, The Netherlands).

(C) 2021 by the authors; licensee Cogitatio (Lisbon, Portugal). This article is licensed under a Creative Commons Attribution 4.0 International License (CC BY).

\section{Introduction}

Social media has become a loudspeaker for anyone wishing to publicly denounce complex situations that women still have to deal with these days: Violence in their homes, sexual harassment or discrimination in the workplace. Contents circulating around these networks demonstrate a wide-reaching social problem, and also bring to light activism driven both by feminist collectives and by individuals. One recent case is the \#MeToo movement which was started in 2006 by the African American activist Tarana Burke, who used 'me too' to offer support and solidarity to a young girl who had confided in her regarding sexual abuse (Hillstrom, 2019).
A decade later, the movement was adopted and amplified by the Hollywood actress Alyssa Milano (Chawla, 2019). Her \#MeToo tweet unleashed a wave of support for women who had been sexually harassed by producer Harvey Weinstein, whilst also encouraging other women to report similar situations in similar contexts, allowing the campaign to spread all over the world with variations on the hashtag (Di Caro, 2017).

The \#MeToo movement exemplifies how, as in the last decade, we have seen an increase in female expression and activism (Pruchniewska, 2016) and how relationships between genders have been reconfigured (Matich, Ashman, \& Parsons, 2019). The developing Internet has been a great ally in this new feminist wave, largely 
responsible for taking the movement to the next levelthe so-called 'fourth-wave feminism' (Benn, 2013)and advertising communication was no stranger to these trends. The appearance of movements such as Femvertising (Bahadur, 2014), that claim to empower women, or campaigns such as Gillette's We Believe: The Best Men Can Be (2019) attempting to banish messages associated with 'toxic masculinity' (Neff, 2019), demonstrates the growing negative reaction to sexist content and objectification of women in persuasive messages. We should not forget that advertising is considered to be a reflection of society (Sánchez, 2003) and at the forefront of social trends, although it also strengthens some of the most archetypal profiles of traditional women (Hurtz \& Durkin, 1997; Khalil \& Dhanesh, 2020; Lysonski, 2015; Napoli \& Murgolo-Poore, 2003; Plakoyiannaki, Mathioudaki, Dimitratos, \& Zotos, 2008).

A decade ago, concern that these social movements have repercussions on and transfer to advertising messages, led our research group to begin analysing female roles and stereotypes in radio advertisements. We decided to choose the radio because it is a medium bound to the present day and immediacy and, therefore, alerts to what is going on around it. Furthermore, historically, before the arrival of audiovisual media, Spanish radio excelled at bringing together advertising, content and a female audience (Balsebre \& Fontova, 2018; Guarinos, 2008). The first study we conducted took place in 2008-2009, two years after the \#MeToo movement began. Considering the movement's poor initial repercussions internationally-particularly the poor media interest it aroused (Leung \& Williams, 2019)-its proximity in time to the research and the lack of data that might provide a comparison, the results gave us a snapshot of the female roles and stereotypes to be found in Spanish radio advertisements, although it is not possible to assess whether changes are taking place in radio advertising. The boom and viral aspects of the \#MeToo movement a decade after its creation, alongside more social movements in favour of women's rights, would lead us to believe that advertising should be part of this new reality. So, the study presented here is a replica of what we carried out in 2008-2009. A decade seems to be long enough for changes to have taken place socially and be reflected in advertising. With this aim, the task involved identifying the main roles and stereotypes in radio advertising insertions through content analysis. To do this, a coding table was drafted featuring 3 major analysis groups and 11 classification categories. In turn, the role category was divided into 10 items that helped us identify the function of the female voice within the advertising item, while the stereotype category was divided into 25 items to be able to classify advertisements based on the image that they projected of women.

Consequently, this article aims to identify the main female roles and stereotypes and analyse these possible changes to female representation in audio advertising. To do so, we have chosen persuasive messages broad- cast by Spanish radio. There are several reasons for this decision. Firstly, Spanish women have historically been the main radio audience in our country and, although the female listener profile has changed substantially over the last few years, the female audience has remained loyal to the radio. Currently, almost half the radio audience in Spain is made up of women (Asociación para la Investigación de Medios de Comunicación, [AIMC], 2020).

Secondly, because the radio is a medium with a high penetration rate among the Spanish population, 55.7\%half of them women-making it the fourth medium after television, outdoor and the Internet. In terms of investment, the situation is similar. The radio sits comfortably among investment for conventional media, varying between third and fourth place (InfoAdex, 2020; Revilla, 2010). Combining the media's penetration figures in our country with the target profile from the gender perspective and the advertising investment received by the medium justifies focussing on the relationship between women, radio advertising content, and the image that this puts across.

Thirdly, studies in relation to gender stereotypes in radio advertising have focused on the role of the voices in the ads from the point of view of linking them to credibility (Bates, Ivanič, \& Somasundaram, 2018; Ivanič, Bates, \& Somasundaram, 2014; Martín-Santana, E. Reinares-Lara, \& P. Reinares-Lara, 2017) or on analysis of gender stereotypes (Diabah, 2019; Furnham \& Thomson, 1999; Hurtz \& Durkin, 1997; Melton \& Fowler, 1987; Neto \& Santos, 2004), but not on the role that we might attribute to radio advertising voices-their ultimate goal-and, at the same time, which image (stereotype) they help create in the recipient's mind.

Fourthly, the scarce number of articles that look in greater depth at the relationship between radio advertising and gender studies (Furnham \& Thomson, 1999; Monk-Turner, Kouts, Parris, \& Webb, 2007) as the majority of these articles concentrated on the medium of television or printed press (Landreth \& Zotos, 2016). This gap is clear in Spain when compared to other media, and the situation does not vary much internationally. The topic of stereotypes and feminine roles has been widely studied using other advertising supports, both audiovisual and graphic (Costa Pereira, Veríssimo, Castillo, \& Correia, 2013; Diabah, 2019; Messias, Veludode-Oliveira, \& Pereira, 2020), but there are barely a dozen contributions on how gender stereotypes are treated on the radio (Diabah, 2019; Fajula, Souto, \& Barbeito, 2009; Furnham \& Schofield, 1986; Furnham \& Thomson, 1999; Gil, 2007; Gil \& Guerrero, 2016; Hurtz \& Durkin, 1997; Lowy, Crespo, \& Roda, 1985; Melton \& Fowler, 1987; Monk-Turner et al., 2007; Neto \& Santos, 2004; Piñeiro-Otero, 2011, 2012). Low interest among researchers can probably be blamed on major advertisers' low presence on the radio, the dominant news style in its commercial messages, the radio's traditional subsidiary role as an advertising medium, the lower potential attributed to radio messages compared to 
television (Gil \& Guerrero, 2016) and the lack of image. Consequently, our article aims to fill the gaps around studies of gender roles and stereotypes in radio advertising and, therefore, provide for a more panoramic and global vision of advertising as a means of transmitting stereotypes in Spain.

\section{Women and Gender Stereotypes in Advertising}

Research on gender stereotypes has proliferated since the 1960s (Napoli \& Murgolo-Poore, 2003), particularly any related to the image projected of women. Traditional stereotypes that put women firmly in the home, as a submissive, sexual object, dependent on men and incapable of making important decisions (Courtney \& Lockeretz, 1971) are increasingly rejected by women who do not feel represented by the image that is projected of them in advertising (Lundstrom \& Sciglimpaglia, 1977). And this is not only rejected by women. Courtney and Whipple (1983) state that, as time goes by, traditional roles tend to bother major segments of consumers. Despite raising the need almost 50 years ago to adhere to women's wishes to be represented in other roles (Courtney \& Lockeretz, 1971) and that there is increasing evidence that many female stereotypes that continue to appear in advertising should be a thing of the past, the advertisers and creators of commercial communication seem to be oblivious to this reality. Although women have made great progress in the job market, advertising is determined to undermine their activity, reflecting not their real behaviour and activity but the idea of how they should behave (Hassanaath, 2020). As a basis for change, the need is raised to improve awareness among advertisers concerning their responsibility to present women on a more equal footing with men (Gallego, 2009; Napoli \& Murgolo-Poore, 2003), without forgetting the role of the media and advertising as opinion leaders (Zhou \& Chen, 1997), agents for socialisation (Wanhsiu, 2010) and broadcasters of desirable behaviour patterns and models (Casado-Mestre, 2005; Navarro \& Martín, 2013). Stereotypes have an impact on society (Ford, Voli, Honeycutt, \& Casey, 1998) because how they represent men and women is perceived as the real image (Zhou \& Chen, 1997).

Encountering traditional female stereotypes in advertising from the 70s might seem normal, but their slow evolution is surprising, even more so the continuity of more negative stereotypes, in some cases even worsening them (Ferguson, Kreshel, \& Tinkham, 1990). More recent studies demonstrate the prevalence of traditional roles associated with women in advertising (Hassanaath, 2020; Knoll, Eisend, \& Steinhagen, 2011) such as presenting women in decorative roles (Landreth \& Zotos, 2016), family-oriented roles or playing second fiddle to men (Uray \& Burnaz, 2003). However, it is also true that the stereotypical image of women has improved over time (Lazar, 2009; Zhou \& Chen, 1997) and advertising tries hard to sell the idea of joint responsibility between men and women, balancing out the presence of women in the public sphere and men in the home (Aramendia, Olarte, \& Hatzithomas, 2020; Lobo, 2011). However, some authors detect a tendency for both realities to co-exist in conflict: On the one hand, a propensity to represent women in traditional roles (Middleton, Turnbull, \& de Oliveira, 2020; Vaca, Carpio, Barrazueta, \& Ordóñez, 2019); and on the other, to show them as assertive, independent, with public presence (Lazar, 2009), linked to more modern roles and figures of authority (Khalil \& Dhanesh, 2020; Michell \& Taylor, 1990).

Spanish, and international, research has particularly focussed on television and the press. These studies not only reveal the persistence of traditional roles (Berganza \& del Hoyo, 2006), but also the scarce evolution of stereotypes over time and their distance from real women (Treviños \& Díaz-Soloaga, 2018), although the stereotypes considered to be most damaging to women, such as housewife and mother (Sánchez, 2003), seemed to be clearly disappearing in the late 20th century (León, 2001), with a further leaning towards adopting characteristics deemed to be masculine, such as being aggressive, imposing and arrogant (Díaz \& Muñiz, 2008). Scarce studies on radio stereotypes in our country demonstrate under-representation of women (Fajula et al., 2009; Gil, 2007; Piñeiro-Otero, 2012), the existence of clearly androcentric advertising (Gil, 2014), giving men and women diametrically opposed roles and the prevalence of traditional roles (Fajula et al., 2009; Piñeiro-Otero, 2011, 2012). The few exceptions that can be found, projecting a current and modern image of women (Gil, 2014), are a ray of hope regarding the radio's potential to break the vicious cycle of sexist stereotypes in radio advertising.

\section{Objectives and Research Method}

In 2008, our research group Publiradio (Autonomous University of Barcelona) analysed female stereotypes in general prime-time radio advertising. The proposal presented here is the replica of this study to observe the evolution of roles and stereotypes in Spanish radio advertising through a longitudinal study.

The research questions are as follows:

RQ1: Can changes be seen in relation to the presence of sexist stereotypes and roles in Spanish radio advertising over the last decade?

This first question is formulated to see how far this is a regressive process and, therefore, as upheld by authors such as Gil and Guerrero (2016), whether archaic values prevail, even when the radio has been improving or 'prettying up' its advertising in this respect or, on the contrary, whether the evolution is positive.

After answering this first question, it is interesting to analyse how current radio advertising presents women, so three further questions are relevant: 
RQ2: What are the dominant roles and stereotypes in Spanish radio advertising?

RQ3: What picture of women does radio advertising paint, as broadcast on the most popular radio stations in Spain?

RQ4: As an advertising vehicle, does the radio still employ traditional roles assigned to women?

The analysis units were extracted from recording programmes on the three main general Spanish radio stations (SER, COPE and Onda Cero) that play advertising. The broadcasters were selected based on data from the General Media Study by the AIMC, the benchmark company in the sector on the Spanish market following maximum audience criteria (AIMC, 2020). The recorded period thereby goes from $9 \mathrm{am}$ to $12 \mathrm{pm}$, coinciding with the highest radio audience levels in Spain (primetime radio). Two series were collected, the first during autumn-winter 2008-2009 and the second in the same period, a decade later, for 2018-2019. Holiday periods (Christmas), bank holidays and weekends were avoided as regular programming and advertising might differ at this time. In both periods, a week was selected at random and the schedule was recorded on one day, also chosen at random. The researchers checked that no substantial changes were made within the advertising schedule for the same week. Recording several days did not reveal an increase in new advertising insertions but in repetition, so the sample was analysed.

In total, 679 advertising insertions were compiled that were broadcast in one day in the given time frames: 440 in the first recording and 239 in the second. The difference between the first sample and the second can be explained by the drop in advertising investment due to the international economic crisis that began in 2008 and due to advertisers' waning interest in the radio medium. Advertising investment in radio reached $€ 537,3$ million in
2009 while this figure had dropped to $€ 486,4$ million by 2019 (InfoAdex, 2020; Revilla, 2010).

The 679 advertising messages were recorded, listened to and the content was analysed. Content analysis "is a procedure for classifying qualitative information to obtain data amenable to quantitative manipulation" (Neto \& Santos, 2004, p. 136) and lets us take a closer look at how the image of women is constructed through radio advertising. It is important to highlight that, the work presented here looks at the concept of role from a dual perspective: Firstly, it handles the concept of role focussed from the point of view of the role played by the woman's voice in the radio advertising item; secondly, it works on the concept of role by assimilating it into the image that is projected of women in the radio advertising items (stereotypes).

To perform the analysis, a template was designed that was structured into different categories (see Table 1). Each advertising insertion was analysed and catalogued within these variables. After identifying whether female voices were present, and how many, in each insertion, all items were labelled within the categories devised regarding the roles of female voices (8) and stereotypes (23) that emerged from listening to advertisements, the specialised literature review and authors' actual knowledge and experience as researchers in the audio advertising field and how gender is treated in advertising (see Tables 2 and 3 ).

For data systematization, a list of variables was drawn up that will represent both the diversity of female roles applied to female voices and also stereotypes (projected image). In the first case, eight roles were defined, considering the main objective of the message and the role played by the female voice. Cases were also considered where the role was not clear or had not been defined and cases where no female voices were present (see Table 2).

Regarding stereotypes, we chose to design an analysis template that will go into greater depth on the classification of roles and stereotypes. To do so, a

Table 1. Analysis units.

\begin{tabular}{ll}
\hline Analysis unit & Variables \\
\hline Item identification & $\bullet$ Item identification number \\
& $\bullet$ Year of broadcast \\
& $\bullet$ Station \\
& $\bullet$ Sector* \\
Commercial/business identification & $\bullet$ Advertiser \\
& $\bullet$ Brand \\
& $\bullet$ Product \\
Advertising item & $\bullet$ Presence of speaker (male/female/both) \\
& $\bullet$ Number of speakers (female/male voices) \\
& $\bullet$ Role of the woman \\
\hline
\end{tabular}

Note: * The taxonomy per sector is based on the InfoAdex classification. 
Table 2. Variables for roles.

\begin{tabular}{ll}
\hline Female voice function & Female voice role \\
\hline Inform & Narrator/interviewer \\
Convince/recommend & Expert/prescriber \\
Persuade & Adviser/friend \\
Identify & User \\
Thrill & Identify with brand values \\
Dramatize & Role-playing within a storytelling \\
Filler & Female voice just as emotional filling \\
Brand image & Represent the brand (brand voice) \\
Not clear/not defined & \\
There is no female voice/not applicable & \\
\hline
\end{tabular}

taxonomy was also drawn up from own data using contributions from Lysonski (1985), McArthur and Resko (1975) and Pérez Gaulí (2000). So, the initial proposal by McArthur and Resko of spouse, parent, homemaker, worker, professional, real-life celebrity, interviewer or narrator, boyfriend/girlfriend and other was included in the list of stereotypes, that was amplified and redefined up to 25 analysis categories (see Table 3).

Table 3. Variables for stereotypes.

\section{Role/stereotype of the woman (projected image)}

Young and modern

Symbol of beauty

Trophy wife

Worker/professional

Empowered/entrepreneur

Rebel/ground-breaker

Expert/prescriber

Clever/knowledgeable

Seductive/persuasive (beauty conscious)

Controlling/gossipy

Independent/initiative-taking/active

Submissive/dependent

Silly/clueless

Exaggerated/unhinged/paranoid

Follower/indecisive

Concerned

Committed woman (social causes)

Shopper/bargain hunter

Mother/carer

Wife/companion

Sexual object (woman as a source of pleasure)

Housewife

Femme fatale

Not clear/not defined

Does not apply

To determine the image that is projected of women in radio advertising, content analysis was run on each of the
679 insertions in the sample to detect if there was content likely to be considered as stereotyped, depending on the classification previously determined for this purpose.

The same researchers - a total of five people, four women and one man-made the recording and encoded it. Discrepancies during classification were pooled and discussed to complete the database they had used. For any items where more than one stereotype was identified, the predominant one was chosen.

\section{Main findings}

\subsection{Roles of Female Voices}

To find out which roles are played by the female voice in radio advertising in Spain, 226 insertions were selected from 2008-2009, 112 from 2018-2019 and 341 items were discarded that did not contain a female voice, and so were classified as 'not applicable.'

The main function that we can identify in the advertising insertions for both series was to inform, where the female voice acts as the narrator or interviewer with the simple aim of putting across information. In any case, this type of advertising differs very little, if at all, from the informative style of radio news blocks. This function of the female voice is found in 162 items from the 2008-2009 period (36.8\% of the total) and in 63 in the 2018-2019 series (26.4\%). It is important to highlight that in these cases, the female voice is not related to a voice of authority, an expert or a prescriber, but seeks something more neutral: Merely putting across information. In many cases, the presence or lack of presence of the female voice is irrelevant so it could be there or not.

If we analyse the results by series, we find that in the first period-2008-2009-the second most prominent role, a long way from the informative role, is that of the product users $(4.3 \%)$, followed by persuading $(3.6 \%)$ where the woman acts as the adviser or friend (see Figure 1). The female voice develops the role of the person who knows the product being advertised and recommends its use. This is followed by the role of the female 


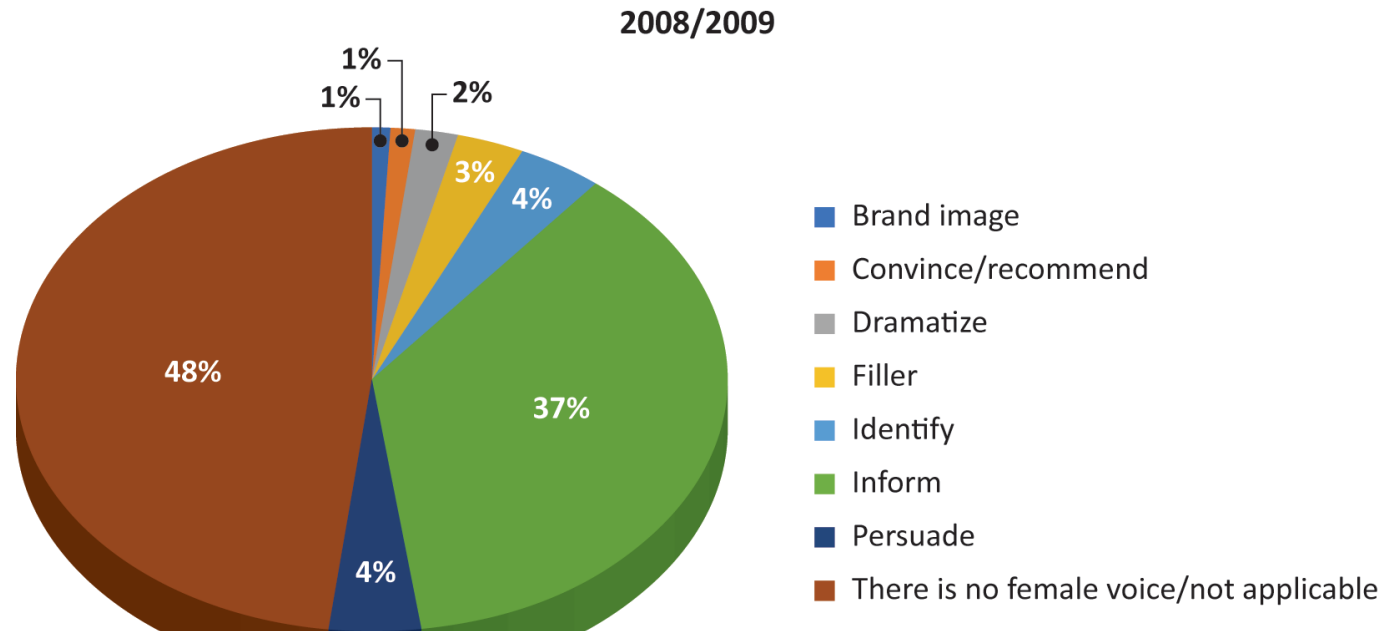

Figure 1. Female roles in 2008-2009.

voice as emotional filling (2.9\%) where the woman's voice aims to move the audience based on giving the communication warmth and the role of dramatizing that we identified as the main speaker playing a certain role in the fictional story (grandmother, mother, girlfriend, worker, etc.) to help put across the story (2\%). As a much more residual representation, we find the brand image role, concentrated on a single advertiser and a single brand: El Corte Inglés. Finally, the role of the woman as an expert/prescriber appears in only $1.3 \%$ of cases, showing the low interest in making women voices of authority.

In the second period-2018-2019-in addition to the role of narrator/interviewer, there are two others that stand out: dramatizing and identifying women as product users, with $7.5 \%$ and $5.8 \%$ respectively. In this series, the role of advisor or friend appears in a smaller number of insertions (2.9\%). The role of women is almost anecdotal as experts or prescribers with $1.6 \%$, as the brand image (also associated with El Corte Inglés; $1.3 \%$ ), emotional filling $(0.8 \%)$ and one insertion that aims to move audiences through the values that the brand puts across (see Figure 2). Comparing the data, we can see how a decade later, there is increased weighting of the role of identifying the woman as the product users and women as the voice of authority remains at practically invisible levels, where she might talk from an expert perspective and not just as a mere consumer. At first glance, it seems that little progress has been made from the point of view of the role that the women's voice develops in Spanish radio advertising, particularly considering that the role that she adopts in her function to put across the advertising message, be it informative or fictional, has repercussions on the image projected of her.

\subsection{Stereotypes of Women in Radio Advertising}

Gender stereotypes can be catalogued in only 5 cases of insertions that did not have a female voice and in

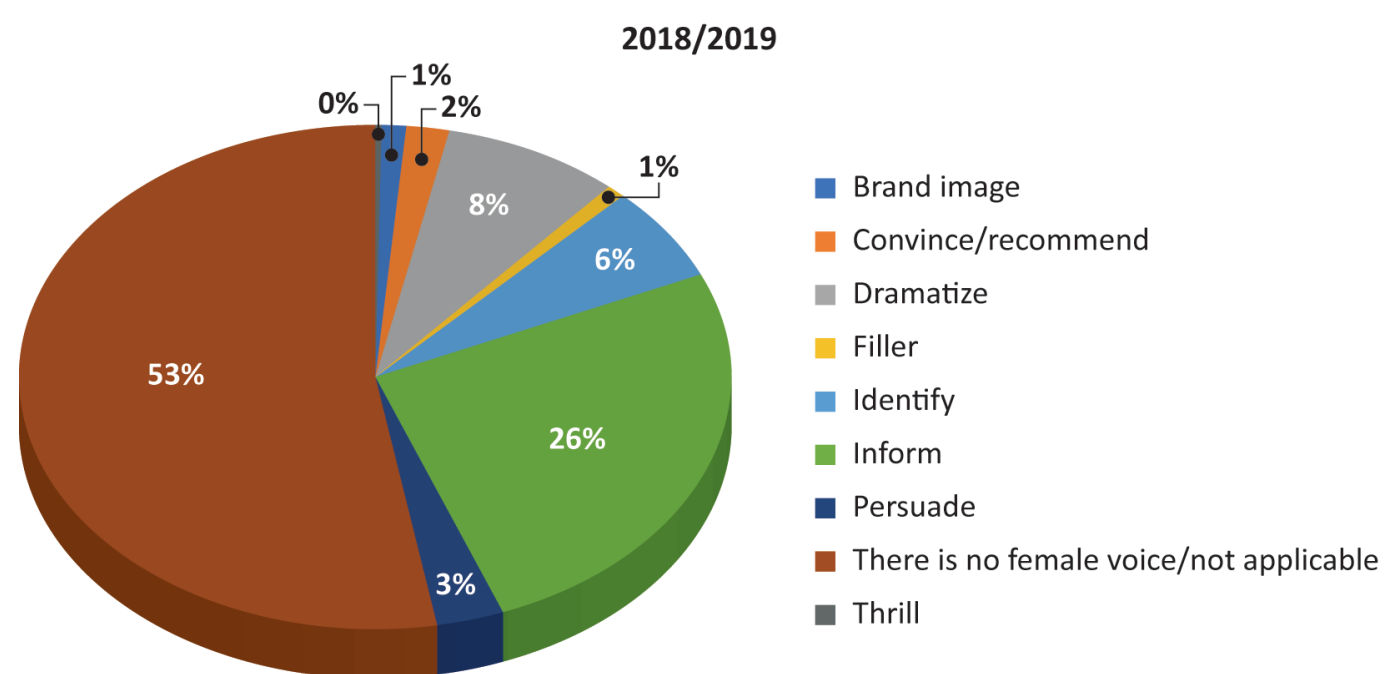

Figure 2. Female roles in 2018/2019. 
16 items where the female voice took the narrator role. Once cases were registered where no stereotype was identified or this was not clear, we were left with 150 analysis units in which we could identify stereotypes associated with women, that represent $22 \%$ of the total sample. 93 insertions correspond to the first series and 57 to the second.

Out of the 23 stereotypes that we defined in theory (without counting the unclear/undefined and not applicable cases), we find 5 stereotypes that were not represented in the sample: the trophy wife, rebel/ ground-breaker, submissive/dependent, silly/clueless and femme fatale.

In Table 4, we locate the number of insertions with the different gender stereotypes in both series. It is interesting to note that the most represented roles in this first series are divided into two clearly different images of women. On the one hand, stereotypes bound to roles that, although they do not portray them directly as a housewife, tie them to domestic tasks or they are associated with a negative stereotyped shopper image. The other most represented role is the symbol of beauty, as if a woman's life goals should include being beautiful. On the other hand, women are portrayed in their role as worker or professional and as someone who knows how to make decisions. In the latter case, the clever/knowledgeable woman, there are two comments: the woman is knowledgeable, and the man looks ridiculous in his ignorance and takes on the role of the fool. However, she is not portrayed as an expert but someone who knows the best thing to buy when shopping. Therefore, although the role has positive nuances in theory, the context means that, once again, the importance of her opinion is minimised: Women don't know about truly important matters.

After a decade, we see that the role of the woman as a symbol of beauty stands in first place while the shopper/bargain hunter has dropped to fourth. The stereotype of the committed woman has risen remarkably where she is portrayed as socially aware and implicated in welfare causes (solidarity, environment, etc.) that moves up to second position in 2018-2019. The other two remarkable changes in this period are the rise in the representation of women as someone who is concerned (by safety, by health, etc.) that moves up to third position with the same number of insertions as the stereotype for the clever/knowledgeable woman and the drop in the role of the woman as a worker/professional for which we only found one item. As for new incorporations in relation to the previous season, we have the roles of the exaggerated/unhinged/paranoid woman, the follower/indecisive woman and the woman as a

Table 4. Female role/stereotypes in both series.

\begin{tabular}{|c|c|c|c|c|c|c|}
\hline $\begin{array}{l}\text { Role/stereotype } \\
\text { (projected image) }\end{array}$ & $\begin{array}{c}\text { No. of } \\
\text { insertions } \\
\text { 2008-2009 }\end{array}$ & $\begin{array}{c}\text { No. of } \\
\text { insertions } \\
2018-2019\end{array}$ & $\begin{array}{l}\text { \% of total } \\
\text { sample } \\
2008-2009\end{array}$ & $\begin{array}{l}\text { \% of total } \\
\text { sample } \\
2018-2019\end{array}$ & $\begin{array}{c}\% \text { of insertions } \\
\text { with stereotypes } \\
2008-2009\end{array}$ & $\begin{array}{c}\% \text { of insertions } \\
\text { with stereotypes } \\
2018-2019\end{array}$ \\
\hline Shopper/bargain hunter & 32 & 6 & 7.3 & 2.5 & 34.4 & 10.5 \\
\hline Symbol of beauty & 13 & 13 & 2.9 & 5.5 & 14 & 22.8 \\
\hline Clever/knowledgeable & 12 & 7 & 2.7 & 2.9 & 12.9 & 12.3 \\
\hline Worker/professional & 7 & 1 & 1.6 & 0.4 & 7.5 & 1.75 \\
\hline Empowered/entrepreneur & 6 & 0 & 1.4 & 0 & 6.5 & 0 \\
\hline Mother/carer & 5 & 2 & 1.1 & 0.8 & 5.4 & 3.5 \\
\hline Young and modern & 4 & 0 & 0.9 & 0 & 4.3 & 0 \\
\hline Committed & 3 & 8 & 0.7 & 3.4 & 3.2 & 14.05 \\
\hline $\begin{array}{l}\text { Independent/initiative- } \\
\text { taking/active }\end{array}$ & 3 & 4 & 0.7 & 1.7 & 3.2 & 7 \\
\hline Expert/prescriber & 2 & 1 & 0.5 & 0.4 & 2.1 & 1.75 \\
\hline Concerned & 2 & 7 & 0.5 & 2.9 & 2.1 & 12.3 \\
\hline Controlling/gossipy & 1 & 0 & 0.2 & 0 & 1.1 & 0 \\
\hline Sexual object & 1 & 0 & 0.2 & 0 & 1.1 & 0 \\
\hline Seductive/persuasive & 1 & 0 & 0.2 & 0 & 1.1 & 0 \\
\hline Housewife & 1 & 1 & 0.2 & 0.4 & 1.1 & 1.75 \\
\hline Wife/companion & 0 & 5 & 0 & 2.1 & 0 & 8.8 \\
\hline $\begin{array}{l}\text { Exaggerated/unhinged/ } \\
\text { paranoid }\end{array}$ & 0 & 1 & 0 & 0.4 & 0 & 1.75 \\
\hline Follower/indecisive & 0 & 1 & 0 & 0.4 & 0 & 1.75 \\
\hline Total & 93 & 57 & 21.1 & 23.8 & 100 & 100 \\
\hline
\end{tabular}


wife/companion. On the other hand, the young and modern roles, controlling/gossipy, empowered/entrepreneur, seductive/persuasive are not represented in this second series.

\section{Conclusions}

In the midst of the 21st century, women are claiming their right to play an active role in society and discard the routines, customs and stereotypes that have symbiotically bound them to the facets of mothers, carers, wives, housewives and sexual objects. Film, art, literature and advertising have nurtured some of the foulest stereotypes of traditional women and, although they should be buried by the passing of time and the boom of feminist movements, we see how in the case of Spanish radio advertising, this evolution is slow and, in some cases, even seems to be taking a step backwards rather than forwards in line with findings by Ferguson et al. (1990). At the start of our research, we wondered if it might be possible to see changes in radio advertising (RQ1) and if there was continued use of roles and stereotypes traditionally assigned to women (RQ4). The analysis of 679 radio advertising insertions collected in two series, 10 years apart, shows few changes regarding the image projected of women and reaffirms that women are still being portrayed in significantly traditional roles.

In relation to $R Q 2$, the results obtained show women represented through stereotyped formulas with two clearly opposing images. On the one hand, they are portrayed through traditional stereotypes as symbols of beauty, shoppers, mothers and carers or wives and companions. On the other, representations are used that attempt to break these more classic stereotypes by giving them traits linked to working women who are professional, independent, take the initiative, active, modern or entrepreneurial. The results coincide with findings from other studies which have also analysed gender stereotypes in radio advertising (Diabah, 2019). The dominant stereotypes show a clear tendency to polarise the image of women and they do not demonstrate a clear step back in the presence of more traditional roles.

The persistence of traditional roles demonstrates a trend among advertisers to put across an image of traditional women along the line of the results obtained in other research (Berganza \& del Hoyo, 2006; Furnham \& Schofield, 1986; Hurtz \& Durkin, 1997). In relation to RQ3, Spanish radio advertising projects a predominantly sexist, classic image with many negative rather than positive attributes for women.

There is a noticeable boom in the role of the concerned woman and the committed woman, whose presence has multiplied by 6 and 5 respectively, over 10 years. In the first case, the context derived from the economic crisis begun in 2008 might help to explain the stereotype of a woman concerned by security (home, family, economic stability, etc.). In the second case, the increase in ecological awareness and commitment to social causes is reflected by including a woman in advertising who is committed to disadvantaged people and care for the environment. We should not forget that the average donor in Spain is a woman aged 49, married or with a stable partner and with qualifications (Kantar Millward Brown \& Asociación Española de Fundraising, 2018), so it comes as no surprise that we see this profile reproduced in radio advertising.

Men usually take on the role of narrators from the point of view of the expert or prescriber whilst this role is entirely residual among women (Furnham \& Thomson, 1999; Hurtz \& Durkin, 1997). In this respect, it is remarkable that the results obtained in 2018-2019 do not differ from the findings of the first studies on stereotypes in radio advertising. McArthur and Resko (1975) already concluded that men had a dominant role to play in advertising with scientific and rational articles and they were presented to a greater extent as experts and voices of authority. Neto and Santos (2004) came to the same conclusions. Almost 45 years after the initial snapshot, Spanish radio advertising is practically the same.

To counter the practical invisibility of women as a voice of authority, it is usual to find her taking the role of user of a certain product and giving advice from her own experience, as a friend. Although in theory this became negative over a long period, as it seems to deny women their capability to act as an expert voice, in the current context, it might be positive. The boom of the Internet and social media has caused a complete turnaround in relation to the type of communication that consumers trust. The success of platforms such as TripAdvisor, services such as Trusted Shops and the proliferation of user reviews and opinions on most websites makes it clear that we trust opinions from other consumers, real users, more than the brand, as we consider consumer opinions are neither conditioned nor interfered with. In this context, the role of women as users, advisers and friends has a greater chance of seeming credible and will give positive results for the brand.

The absence of evidence of images, control of the informative style in radio advertising and the fact that certain business sectors do not include radio in their media strategy leads to lower presence of insertions with stereotyped content. This can help explain the low interest raised by research into gender stereotypes in radio advertising compared to studies found on this same topic referring to the television or printed media. The scarcer presence of stereotypes can lead to a false sensation that they do not exist when, as we have seen, this is not the case. Radio advertising presents indices of stereotyped content which are similar to what we found in television (Neto \& Santos, 2004). It is interesting to highlight that stereotyping women as sexual objects does not appear on radio advertising while it is usually one of the predominant stereotypes in graphic and audiovisual media (Chacón, 2008). In these media, this usually implies a tactic to attract the recipient's attention (Kerin, Lundstrom, \& Sciglimpaglia, 1979) using a sensual-sexual, 
highly idealised image. The lack of image, as we mentioned, surely explains the absence of this stereotype in radio advertising.

The scrutiny to which television is subjected in its current role, with a nod to the Internet, of prime medium among certain segments of the Spanish population, means that stereotypes such as the housewife have disappeared from TV advertising (Martín Casado, 2012). On the other hand, the label of second-class medium that has been traditionally given to the radio in Spain helps more traditional stereotypes last longer, such as those we have just mentioned.

There has been a remarkable change among advertising items between the first and second series. While in the first series, the pressure to attain an ideal of beauty exclusively targeted women, in the second period, we see this pressure being transferred to men. In this case, the iconographic model that is held up is mesomorph (athletic) for men and endomorph (slim) for women.

Radio as an advertising medium linked to proximity, above all thanks to local programming, makes it easier to appeal directly to the recipient to behave in a certain way. In our case, one of the most widely represented stereotypes in both series is the shopper/bargain hunter woman and we saw how the El Corte Inglés advertiser makes the most of advertising insertions by mentioning that its stores open at $10 \mathrm{am}$ as a reminder to incite purchase.

To sum up, the results obtained are quite consistent with the studies that we could find internationally on gender radio advertising which implies, on the one hand, that many of the stereotypes are universal and transcend cultures and borders. On the other, obtaining similar results so many years apart demonstrates the slow evolution of radio advertising. The longitudinal study presented here is, as mentioned by Milner and Higgs (2004), one of the few attempts to look at the evolution of stereotypes internationally and beyond the English-speaking world (United States or United Kingdom). Furthermore, the longitudinal studies that we could find are focussed on the television, so this contribution is important as it allows us to analyse the changes made in radio advertising over time. Doubtlessly, the continuity of the study will make it possible to document the presence, persistence, appearance and/or disappearance of gender stereotypes in Spanish radio advertising in the future as society's perception of these stereotypes moves forward and changes. In the same way, it opens the door to similar studies in other countries to obtain comparative findings. We consider that the range of roles and stereotypes presented in this research can be easily extrapolated to other regions.

Finally, we should mention that most consumers are accustomed to receiving advertising messages with stereotyped content so that often we barely pay attention to them or we simply consider them as 'normal.' We hope that this study can 1) encourage insight on the persistence of content that uses roles and stereotypes traditionally assigned to women despite social achievements, and 2) help activate our critical awareness on the content of persuasive messages and the image that they project regarding gender. In the same way, a change in attitude towards gender equality would be desirable, both from whoever commissions advertising and the people creating it. This research seems to reveal a major disconnection between radio advertising and society, demonstrated by the slow pace and difficulty to transform stereotypical content of radio advertising messages.

\section{Conflict of Interests}

The authors declare no conflict of interests.

\section{References}

Aramendia, M. E., Olarte, C., \& Hatzithomas, L. (2020). Gender stereotypes in original digital video advertising. Journal of Gender Studies, 29(4), 403-419. https://10.1080/09589236.2019.1650255

Asociación para la Investigación de Medios de Comunicación. (2020). Resumen general estudio general de medios [Overall media study summary]. Asociación para la Investigación de Medios de Comunicación. Retrieved from https://reporting.aimc.es/ index.html\#/main/cockpit

Bahadur, N. (2014, October 3). 'Femvertising' ads are empowering women: And making money for brands. Huffington Post. Retrieved from https://cutt. ly/Bh4Pssp

Balsebre, A., \& Fontova, R. (2018). El consultorio de Elena Francis: El discurso religioso como elemento de control de la conducta femenina [Elena Francis in sesión: Religious discourse as an element of controlling female behaviour]. Alcores: Revista de Historia Contemporánea, 22, 89-109.

Bates, K., Ivanič, A. S., \& Somasundaram, T. (2018). Accents and ethnic stereotypes in radio advertising: Implications for spokesperson selection. Advertising \& Society Quarterly, 19(4). https://doi.org/10.1353/ asr.2018.0033

Benn, M. (2013). After post-feminism: Pursuing material equality in a digital age. Juncture, 20(3), 223-227. https://doi.org/10.1111/j.2050-5876.2013.00757.x

Berganza, M. R. C., \& del Hoyo, M. H. (2006). Women and men in television advertising: Images and stereotypes. ZER: Revista de Estudios de Comunicación, 21, 161-175. Retrived from https://addi.ehu.es/ bitstream/handle/10810/40909/3730-13020-1PB.pdf?sequence $=1$ \&isAllowed $=y$

Casado-Mestre, F. (2005). TV as a way of social behaviour: A pedagogical proposal. Comunicar, 13(25). https://doi.org/10.3916/C25-2005-196

Chacón, P. D. (2008). La mujer como objeto sexual en la publicidad [The use of women as sex objects in advertising]. Comunicar: Revista científica Iberoamericana de comunicación y educación, 31(16), 403-409. 
Chawla, D. (2019). My \#MeToos before the \#MeToo. Women \& Language, 42(1), 165-168.

Costa Pereira, F., Veríssimo, J., Castillo, A. D., \& Correia, R. (2013). Gender stereotyping, sex and violence in Portuguese and Spanish advertisement. Comunicação e Sociedade, 23, 274-292. https://doi.org/10.17231/comsoc.23(2013).1626

Courtney, A. E., \& Lockeretz, S. W. (1971). A woman's place: An analysis of the roles portrayed by women in magazine advertisements. Journal of Marketing Research, 8(1), 92-95. https://doi.org/10.1177/ 002224377100800114

Courtney, A. E., \& Whipple, T. W. (1983). Sex stereotyping in advertising. Lanham, MD: Lexington Books.

Diabah, G. (2019). The representation of women in Ghanaian radio commercials: Sustaining or challenging gender stereotypes? Language in Society, 48(2), 261-283. https://doi.org/10.1017/ S0047404518001343

Díaz, P., \& Muñiz, C. (2008). Women stereotypes portrayed in print ads by luxury fashion brands: A content analysis from 2002 to 2005 . Observatorio (OBS*) Journal, 14, 291-305.

Di Caro, B. (2017, October 18). \#MeToo, \#balancetonporc, \#yotambien: Women around the world fight back at harassment. World Economic Forum. Retrieved from https://www.weforum.org/agenda/ 2017/10/metoo-balancetonporc-yotambienwomen-around-the-world-lash-out-at-harassment

Fajula, A., Souto, A. B. F., \& Barbeito, M. L. (2009). Publicidad y género: Los estereotipos de la mujer en la publicidad radiofónica del 'prime time' generalista [Advertising and gender: Stereotypes of women in generalist prime time radio advertising]. In J. Gallego, N. Abuín, \& Ò. Guasch (Eds.), Actes de congènere: La representació de gènere a la publicitat del segle XXI [The representation of gender in 21st century advertising] (pp. 1-19). Girona: Universitat de Girona. Retrieved from http://www3.udg.edu/publicacions/ vell/electroniques/congenere/comunicacions/pdf/

11_Publicidad_y_Genero.pdf

Ferguson, J. H., Kreshel, P. J., \& Tinkham, S. F. (1990). In the pages of Ms.: Sex roles portrayals of women in advertising. Journal of Advertising, 19(1), 40-51. https://doi.org/10.1080/00913367.1990.10673179

Ford, J. B., Voli, P. K., Honeycutt, E. D., Jr., \& Casey, S. L. (1998). Gender role portrayals in Japanese advertising: A magazine content analysis. Journal of Advertising, 27(1), 113-124. https://doi.org/ 10.1080/00913367.1998.10673546

Furnham, A., \& Schofield, S. (1986). Sex-role stereotyping in British radio advertisements. British Journal of Social Psychology, 25(2), 165-171. https://doi.org/ 10.1111/j.2044-8309.1986.tb00715.x

Furnham, A., \& Thomson, L. (1999). Gender role stereotyping in advertisements on two British radio stations. Sex Roles, 40, 153-165. https://doi.org/ 10.1023/A:1018890719743
Gallego, J. (2009). La construcción del género a través de la publicidad [The construction of gender through advertising]. In J. Gallego, N. Abuín, \& Ò. Guasch (Eds.), Actes de congènere: La representació de gènere a la publicitat del segle XXI [The representation of gender in 21st Century Advertising] (pp. 119). Girona: Universitat de Girona. Retrieved from http://www3.udg.edu/publicacions/vell/ electroniques/congenere/comunicacions/pdf/ 11_Publicidad_y_Genero.pdf

Gil, E. M. (2007). Los estereotipos de la mujer en la publicidad radiofónica [Stereotypes of women in radio advertising]. In M. A. Duran \& M. V. García (Eds.), Mujeres, simbolismo y vida: Estudios sobre mujeres [Women, symbolism and life: Women's studies] (pp. 79-96). Málaga: Servicio de publicaciones Universidad de Málaga.

Gil, E. M. (2014). Mujeres y hombres en el discurso publicitario radiofónico (2004-2010) [Women and men in radio advertising discourse (2004-2010)]. Boletín de la Sociedad de Amigos de la Cultura de Vélez-Málaga, 13, 21-24.

Gil, E. M., \& Guerrero, S. (2016). Principales estereotipos en la publicidad radiofónica española [Main stereotypes in Spanish radio advertising]. Madrid: Fundamentos.

Guarinos, V. (2008). Mujer, radio y canción de consumo [Women, radio and consumption song]. In F. Loscertales \& T. Núñez (Eds.), Los medios de comunicación con mirada de género [Media from a gender perspective] (pp. 221-240). Seville: Junta de Andalucía, Instituto Andaluz de la mujer. Retrieved from https://idus.us.es/xmlui/bitstream/handle/ $11441 / 26774 /$ mujerradioycancion.pdf?sequence $=1$

Hassanaath, B. (2020). Gender stereotypes in advertising: A critical discourse analysis. Language in India, 20(1), 45-55.

Hillstrom, L. C. (2019). The \#MeToo movement. California, CA: ABC-CLIO.

Hurtz, W., \& Durkin, K. (1997). Gender role stereotyping in Australian radio commercials. Sex-Roles, 36(1/2), 103-114. https://doi.org/10.1007/BF02766241

InfoAdex. (2020). Estudio InfoAdex de la inversión publicitaria en España [InfoAdex study of advertising investment in Spain]. Madrid: InfoAdex. Retrieved from https://www.infoadex.es/home/wp-content/ uploads/2020/02/NP-Estudio-InfoAdex-de-laInversión-Publicitaria-en-España-2020.pdf

Ivanič, A., Bates, K., \& Somasundaram, T. (2014). The role of the accent in radio advertisements to ethnic audiences. Journal of Advertising Research, 54(4). https:// 10.2501/JAR-54-4-407-419

Kantar Millward Brown, \& Asociación Española de Fundraising. (2018). La colaboración de los españoles con las entidades no lucrativas [Spaniards' Collaboration with Non-Profit Organizations]. New York, NY, and Madrid: Kantar Millward Brown and Asociación Española de Fundraising. Retrieved from 
https://www.aefundraising.org/wp-content/ uploads/2017/09/Resumen-Ejecutivo-Perfil_ Donante_2018_DEF.pdf

Kerin, R. A., Lundstrom, W., \& Sciglimpaglia, D. (1979). Women in advertisements: Retrospect and prospect. Journal of Advertising, 8(3), 37-42. https://doi.org/ 10.1080/00913367.1979.10673287

Khalil, A., \& Dhanesh, G. (2020). Gender stereotypes in television advertising in the Middle East: Time for marketers and advertisers to step up. Business Horizons, 63(5), 671-679. https://doi.org/10.1016/ j.bushor.2020.05.004

Knoll, S., Eisend, M., \& Steinhagen, J. (2011). Gender roles in advertising. International Journal of Advertising, 30(5), 867-888. https://doi.org/10.2501/IJA-305-867-888

Landreth, S., \& Zotos, Y. C. (2016). Gender stereotypes in advertising: A review of current research. International Journal of Advertising, 35(5), 761-770.

Lazar, M. M. (2009). Entitled to consume: Postfeminist femininity and a culture of post-critique. Discourse \& Communication, 3(4), 371-400. https://doi.org/ $10.1177 / 1750481309343872$

León, J. L. (2001). Mitoanálisis de la publicidad [Mythoanalysis of advertising]. Barcelona: Ariel editorial.

Leung, R., \& Williams, R. (2019). \#MeToo and intersectionality: An examination of the \#MeToo movement through the R. Kelly scandal. Journal of Communication Inquiry, 43(4), 349-371. https://doi.org/ $10.1177 / 0196859919874138$

Lobo, C. (2011). Female stereotypes in household appliances advertising and their social role in Spain: The perpetuation of a no-longer-existing female condition. Textual \& Visual Media, 4, 99-120.

Lowy, A., Crespo, E., \& Roda, R. (1985). La imagen de la mujer en la radio: Análisis [The image of women on the radio: Analysis]. Madrid: Instituto de la Mujer.

Lundstrom, W., \& Sciglimpaglia, D. (1977). Sex role portrayals in advertising. Journal of Marketing, 41(3), 72-79. https://doi.org/10.1177/ 002224297704100308

Lysonski, S. (1985). Role portrayals in British magazine advertisements. European Journal of Marketing, 19(7), 37-55. https://doi.org/10.1108/ EUM0000000004724

Lysonski, S. (2015). Sex-role stereotyping in advertisements: A re-examination. In J. Rogers III \& C. Lamb Jr. (Eds.), Proceedings of the 1983 Academy of Marketing Science (AMS) annual conference: Developments in Marketing Science (pp. 461-464). Cham: Springer. https://doi.org/10.1007/978-3-319-16937-8_110

Martín Casado, T. G. (2012). La mujer en la creatividad publicitaria del siglo XXI: De protagonista a profesional del mensaje publicitario [Women in advertising creativity in the 21st century: From protagonist to professional of the advertising message]. Communication Papers, 1, 105-114. https://doi.org/10.33115/ udg_bib/cp.v1i01.22142
Martín-Santana, J. D., Reinares-Lara, E., \& Reinares-Lara, P. (2017). Influence of radio spokesperson gender and vocal pitch on advertising effectiveness: The role of listener gender. Revista Española de marketingESIC, 21(1), 63-71. https://10.1016/j.sjme.2017.02. 001

Matich, M., Ashman, R., \& Parsons, E. (2019). \#freethenipple: Digital activism and embodiment in the contemporary feminist movement. Consumption, Markets \& Culture, 22(4), 337-362. https://doi.org/10.1080/10253866.2018.1512240

McArthur, L. Z., \& Resko, B. G. (1975). The portrayal of men and women in American television commercials. The Journal of Social Psychology, 97(2), 209-220. https://doi.org/10.1080/00224545.1975.9923340

Melton, G. W., \& Fowler, G. L., Jr. (1987). Female roles in radio advertising. Journalism \& Mass Communication Quarterly, 64(1), 145-149. https://doi.org/10.1177/ 107769908706400120

Messias, L., Veludo-de-Oliveira, T., \& Pereira, I. (2020). Beyond gender stereotypes: The missing women in print advertising. International Journal of Advertising. Advance online publication. https://doi.org/ 10.1080/02650487.2020.1820206

Michell, P. C. N., \& Taylor, W. (1990). Polarising trends in female role portrayals in UK advertising. European Journal of Marketing, 24(5), 41-49.

Middleton, K., Turnbull, S., \& de Oliveira, M. J. (2020). Female role portrayals in Brazilian advertising: Are outdated cultural stereotypes preventing change? International Journal of Advertising, 39(5), 679-698. https://doi.org/10.1080/02650487.2019.1658428

Milner, L. M., \& Higgs, B. (2004). Gender sex-role portrayals in international television advertising over time: The Australian experience. Journal of Current Issues and Research in Advertising, 26(2), 81-95. https:// doi.org/10.1080/10641734.2004.10505166

Monk-Turner, E., Kouts, T., Parris, K., \& Webb, C. (2007). Gender role stereotyping in advertisements on three radio stations: Does musical genre make a difference? Journal of Gender Studies, 16(2), 173-182. https://doi.org/10.1080/09589230701324736

Napoli, J., \& Murgolo-Poore, M. (2003). Female gender images in adolescent magazine advertising. Australian Marketing Journal, 11(1), 60-69. https://doi.org/10.1016/S1441-3582(03)70118-9

Navarro, M., \& Martín, M. (2013). Análisis bibliométrico de la investigación sobre mujer y publicidad: Diferencias en medios impresos y audiovisuales [Bibliometric analysis of research on women and advertising: Differences in print and audiovisual media]). Comunicar, 21(41), 101-110.

Neff, J. (2019). Gillette's 'the best men can be' and the war on toxic masculinity: Despite backlash from conservative critics, P\&G's shaving brand doubles down on progressive campaign. Advertising Age, 90(19), 24.

Neto, F., \& Santos, A. (2004). Gender role stereo- 
typing in radio advertisements: A Portuguese and cross-national analysis. Journal of Radio Studies, 11(1), 131-145. https://doi.org/10.1207/s15506843 jrs1101_11

Pérez Gaulí, J. C. (2000). El cuerpo en venta: Relación entre arte y publicidad [The body for sale: Relationship between art and advertising]. Madrid: Cátedra.

Piñeiro-Otero, T. (2011). Gender representations in radio advertisements: A comparative analysis. Vivat Academia, 115, 71-94. https://doi.org/10.15178/va. 2011.115.71-94

Piñeiro-Otero, T. (2012). They make, others say, they are: Female roles on Spanish radio advertising. Doxa.comunicación, 14, 99-122.

Plakoyiannaki, E., Mathioudaki, K., Dimitratos, P., \& Zotos, Y. (2008). Images of women in online advertisements of global products: Does sexism exist? Journal of Business Ethics, 83(1), 101-112.

Pruchniewska, U. M. (2016). Working across difference in the digital era: riding two waves to feminist solidarity. Feminist Media Studies, 16(4), 737-741. https:// doi.org/10.1080/14680777.2016.1190045

Revilla, M. Á. S. (2010). Estudio InfoAdex de la inversión publicitaria en España [InfoAdex study of advertising investment in Spain]. Madrid: InfoAdex.
Retrieved from https://www.infoadex.es/home/wpcontent/uploads/2017/12/RESUMEN-2010.pdf

Sánchez, J. J. (2003). Framing the woman's image in advertising. Comunicación y Sociedad, 16(2), 67-92.

Treviños, D., \& Díaz-Soloaga, P. (2018). Female stereotypes in graphic ads of luxury fashion, perfumery \& cosmetic brands. Pensar la Publicidad, 12, 145-164.

Uray, N., \& Burnaz, S. (2003). An analysis of the portrayal of gender roles in Turkish television advertisements. Sex Roles, 48, 77-87. https://doi.org/ 10.1023/A:1022348813469

Vaca, B., Carpio, L., Barrazueta, P., \& Ordóñez, K. (2019). Stereotypes and gender representation in ecuadorian advertising. Revista Iberica de Sistemas e Tecnologias de Informaçao, E26, 335-347.

Wanhsiu, S. T. (2010). Family man in advertising? A content analysis of male domesticity and fatherhood in Taiwanese commercials. Asian Journal of Communication, 20(4), 423-439. https://doi.org/10.1080/ 01292986.2010 .496860

Zhou, N., \& Chen, M. Y. T. (1997). A content analysis of men and women in Canadian consumer magazine advertising: Today's portrayal, yesterday's image? Journal of Business Ethics, 16(5), 485-495. https:// www.jstor.org/stable/25072916

\section{About the Authors}

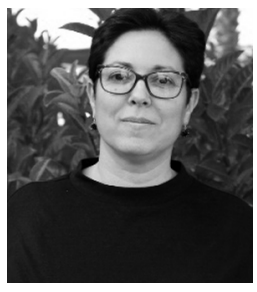

Anna Fajula holds a PhD in Advertising and Public Relations from the Autonomous University of Barcelona (UAB) and is currently a Serra Húnter Lecturer at the Department of Advertising, Public Relations and Audiovisual Communication (UAB), member of the Publiradio Research Group (UAB) and Study and Research Centre in entrepreneurship and Social Innovation (UAB). Her research interests focus on creativity as a strategic element of the new communication environment, advertising creativity, gender treatment in advertising and sound and audiovisual creativity.

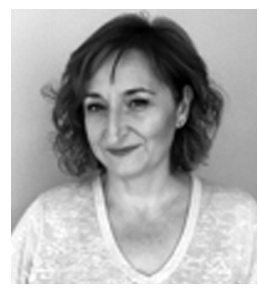

Mariluz Barbeito (PhD) is Serra Húnter Fellow at the Autonomous University of Barcelona (UAB). As a member of Research Group on Advertising and Radio Broadcasting Communication (Publiradio), she has participated in several research projects about consumer habits, audiences and sound content. She focuses her works in sound language, advertising and corporate communication. She has published scientific articles in indexed journals related these topics. Currently, she is the Academic Secretary of the Department of Advertising, Public Relations and Audiovisual Communication in UAB.

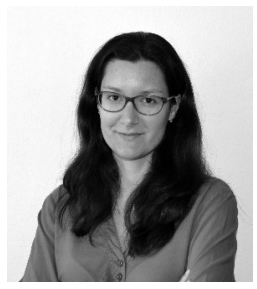

Estrella Barrio holds a PhD in Advertising and PR. She is researcher at the Autonomous University of Barcelona (UAB). Her teaching and research activity is linked to the field of corporate communication, subject on which she has several publications. She is Member of the research group Publiradio, a group belonging to the Department of Advertising, Public Relations and Audiovisual Communication (UAB). She teaches on the BA degrees in Advertising and PR, as well as on MA degree in Communication and Strategic Advertising.

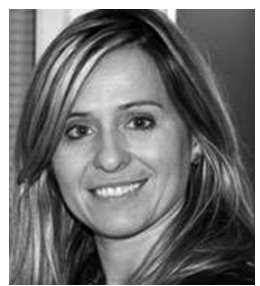

Ana Maria Enrique (PhD) is an ordinary Researcher and Associate Professor at Autonomous University of Barcelona (UAB) and at the Abat Oliba University where she teaches Communication Theories and Business and Institutional Communication. She has published several book chapters and articles related to crisis management and corporate social responsibility. She is Member of the research group Publiradio, a group belonging to the Department of Advertising, Public Relations and Audiovisual Communication (UAB). 
Juan José Perona (PhD) is Associate Professor of Audiovisual Communication and Advertising at the Faculty of Communication Sciences of the Autonomous University of Barcelona (UAB). Since 2009, he is coordinator of the Research Group on Advertising and Radio Broadcasting Communication (Publiradio). He investigates the digital sound-sphere, the radiophonic advertising and the educational radio. He was Dean of the Faculty of Communication Sciences, at UAB (1999-2001), and chief of the Department of Advertising, Public Relations and Audiovisual Communication (2015-2018). 